\title{
A conceptual modeling of ecological greywater recycling system in Kuching city, Sarawak, Malaysia
}

\author{
Darrien Yau Seng Mah*, Charles Hin Joo Bong ${ }^{1}$, Frederik Josep Putuhena ${ }^{2}$, Salim Said ${ }^{3}$ \\ Faculty of Engineering, Civil Engineering Department, Universiti Malaysia Sarawak, km 17 Kuching Samarahan Expressway, \\ 94300 Kuching, Sarawak, Malaysia
}

\section{A R T I C L E I N F O}

\section{Article history:}

Received 31 July 2007

Received in revised form 30 May 2008

Accepted 8 July 2008

Available online 31 December 2008

\section{Keywords:}

Ecological sanitation

Greywater

Kuching city

Recycling

Urban

Water supply

\begin{abstract}
A B S T R A C T
A pilot project of greywater ecological treatment is established in Kuching city since 2003. Such treatment facility opens up an opportunity of wastewater reclamation for reuse as secondary sources of water for non-consumptive purposes. This paper aims in exploring the potential of the intended purposes in the newly developed ecological treatment project. The modeling process of using a mathematical representation of the real system is commonly performed to evaluate a proposed system. By using network simulations, which replicate the dynamics of a proposed system, problems can be anticipated and solutions can be evaluated before time, money and materials are invested in a real-world project. Efforts are made to carry out a hydraulic modeling of a hypothetical greywater recycling system as an integrated part of the Kuching urban water supply using the Wallingford Software model, InfoWorks Water Supply (WS). The modeling efforts where the greywater is treated, recycled and reused in the domestic environment have shown water saving of about $40 \%$. This model assists the researcher to evaluate the performance of the recycling system in the context of shifting towards more integrated water resources management.
\end{abstract}

(C) 2008 Elsevier B.V. All rights reserved.

\section{Background}

Kuching is the capital city of the East Malaysia State of Sarawak, established at the banks of Sarawak River on the North-Western part of Borneo Island. The longitude and latitude of Kuching is $01^{\circ} 33^{\prime} \mathrm{N}, 110^{\circ} 25^{\prime} \mathrm{E}$. Kuching is the most populous city in the state, with a population of 579, 900 (2006 census) and a density of $322 \mathrm{~km}^{-2}$.

Kuching Water Board is the responsible authority to supply clean water for the Kuching city. Its jurisdiction supply boundary covers an area of $730 \mathrm{~km}^{2}$. The Sarawak Public Works Department is managing the public water supply services to rural areas under its Water Supply Section. The Board has long relied on its Batu Kitang water treatment plant upstream of Sarawak River for more than $97 \%$ of water production. Though Sarawak River system as the main freshwater abstraction for the capital city is fortunately rich in its reserve

\footnotetext{
* Corresponding author. Tel.: +60 82 583246; fax: +60 82583409.

E-mail addresses: darrien_mah@yahoo.co.uk (D.Y.S. Mah), bhjcharles@feng.unimas.my (C.H.J. Bong),fjputuhena@feng.unimas.my (F.J. Putuhena), ssalim@feng.unimas.my (S. Said).

1 Tel.: +60 82 583277; Fax: +60 82583409 .

2 Tel.: +60 82 583349; fax: +60 82583409 .

${ }^{3}$ Tel.: +60 82 583264; fax: +60 82583409 .
}

and hydrology, this advantaged physical environment is increasingly challenged when placed in the context of the dynamic social environment of Kuching city. Kuching city is the fastest growing area placing great pressure on the water supply and has seen a rapid growth in water demand.

Effectively managing the water supply and demand requires a sustainable approach that manages the natural resource together with community demands, both consumptive and uses, and not forgetting also the environment needs. The local practiced water supply management still focuses on strategic direction and priorities revolved around water supply, infrastructure, water reticulation and management of water storages. Sustainable water supply into the future would embrace the concept of Integrated Water Resources Management (IWRM) where the new challenge requires a very different response.

To cater for a change for sustainable and ecologically efficient use of water supply, water resources and wastewater management must come together in addressing the water cycle under the IWRM processes. Diversifying the supply options is one way to reduce dependency on sole sources of supply (Mkandla et al., 2005; Hiessel, 2002). In order to decrease the pressure on the finite water resources, wastewater need not be throwing away after one time use but can be prompted for reclamation of household wastewater. Recycling and reuse of wastewater can be a water source for nonconsumptive purposes where lesser quantities of potable water are 